\title{
Investigation of the principal vectors of abortive diseases in one-humped camels (Camelus dromedarius)
}

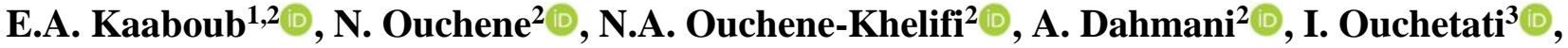

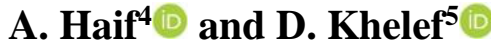

${ }^{1}$ Department of Natural and Life Sciences, Faculty of Sciences, University Yahia Fares of Medea, New University Pole, Medea, ${ }^{2}$ Institute of Veterinary Sciences, Laboratory LBRA, University SAAD Dahlab Blida 1, Road Soumaa, BP 270, Blida, ${ }^{3}$ Normal High School of Technological Education, University of Skikda, Skikda, ${ }^{4}$ Department of Veterinary Sciences, University of El Tarf, El Tarf, ${ }^{5}$ National High Veterinary School of Algiers, 16000, Algiers, Algeria

\begin{tabular}{l} 
Article information \\
\hline Article history: \\
Received April 10, 2020 \\
Accepted May 14, 2020 \\
Available online June 23, 2021 \\
\hline Keywords: \\
Abortion \\
Camels \\
Ouargla \\
Ticks \\
Vector-borne diseases \\
\hline Correspondence: \\
N.A. Ouchene-Khelifi \\
ouchenassim@gmail.com
\end{tabular}

\begin{abstract}
One-humped camels (Camelus dromedarius) are important source of meat, milk and leather production for humans in southern Algeria. Camel livestock farming is confronted with several obstacles, including abortive diseases which can be transmitted mainly by ticks. The study was carried out in Ouargla region, South Algeria, between January and December 2017. The objective of this study was to identify ticks in camels and to study the relationship between camel abortion rate and the presence of different species of ticks. A total of 350 camels (including 171 males and 179 females) was used in this study. Ticks were searched on the entire camel body (head, neck, hump, abdomen, forelegs, back legs, and tail area). Results showed that $215 / 350(61.4 \%)$ camels were infested by ticks including $137 / 171$ $(80.1 \%)$ and $78 / 179(43.6 \%)$ males and females, respectively. A total of 46/179 (25.7\%) camel females had aborted and all these were revealed infested by ticks. A total of 298 ticks was collected including the following species Hyalomma dromedarii (90.9\%), Hyalomma impeltatum (5.37\%) and for the first time in Algeria, Amblyomma variegatum (2.35\%) and Rhipicephalus turanicus $(1.34 \%)$. H. dromedarii was the most frequent $(\mathrm{p}<0.001)$. The study showed that the dromedary was highly infested by ticks. The presence of ticks in all aborted female camels certainly indicates their important role in one-humped camel abortions in Algeria. The identification of tick-borne abortive agents in camels is important in order to establish an effective abortion control plan.
\end{abstract}

DOI: 10.33899/ijvs.2020.126914.1415, (C2021, College of Veterinary Medicine, University of Mosul. This is an open access article under the CC BY 4.0 license (http://creativecommons.org/licenses/by/4.0/).

\section{Introduction}

Ticks are a worldwide major group of arthropod vectors that can transmit different types of pathogens with impact on human and animal health. They may be observed in highly varied habitats, from the driest to the most humid (1). Pathogens transmitted among animals by arthropod vectors, mainly ticks, have been responsible for significant morbidity and mortality worldwide (2-6). Abortions have been suggested as the main causes of reproductive failure and infertility of camels and its rates ranging from $10 \%$ to over $70 \%$ in some areas $(7,8)$. In camels, tick-borne pathogens that can cause abortion include Coxiella burnetii $(9,10)$, Theileria (11) and Anaplasma (12-14). The vector of abortive pathogens is a hematophagous arthropod that allows the active or biological transmission of these pathogens between vertebrates. Ticks are the most important vectors of vector-borne abortive diseases in terms of animal health $(1,3$ $6)$. In Algeria, the total number of camels was estimated at 344015 with majority of them is in the Sahara Desert (15). 
Camels represent a definite economic interest in Sahara Desert, and remain main source of animal protein for the Saharan population (16). Parasitic diseases are a major pathological disease of the Algerian camels, in particular tick infestation $(17,18)$. Limited information is available concerning abortion in camels that are associated to ticks in Algeria. Therefore, this study was carried out, in Ouargla region, southern Algeria, to study the relationship between camel abortion rate and the presence of different species of ticks known as vectors of abortive pathogens in camel farms.

\section{Materials and methods}

\section{Study Animals}

The study used 350 camels (included 171 males and 179 females) located in Ouargla region, southern Algeria (Longitude $5^{\circ} 19^{\prime} 30^{\prime \prime} \mathrm{E}$, Latitude $31^{\circ} 56^{\prime} 57^{\prime \prime} \mathrm{N}$ and altitude $138 \mathrm{~m}$ ) that is characterized by an arid Saharan climate, rainfall of less than $100 \mathrm{~mm}$ per year and average temperatures exceeding $40^{\circ} \mathrm{C}$ (15). Over a period between January and December 2017, ticks have been inspected throughout the animal's body, particularly at thin skin areas (ears, testicles, udders, inguinal region). Only one tick sample was collected from each animal. Four camel age categories (in years) were considered in this study: $<1,1-4$, $5-8$, and $>8$. The aborted females were identified by seeing the aborted fetus during our visit.

\section{Laboratory diagnosis}

Ticks were collected and stored in vials containing $70^{\circ}$ alcohols, and were identified under a binocular loupe using the key of Walker et al. (19).

\section{Statistical analysis}

The statistical program used was $\mathrm{R}$ i386 3.0.2 for Windows GUI front-end. Chi-square test was applied to compare the tick infestation rate in camels with regard to abortion, sex, age, and season. It was also used to compare between the proportions of different tick species. The threshold value of different tests was $\mathrm{P}<0.05$.

\section{Results}

A total of 215/350 (61.4\%) camels was infested by ticks, including 137/171 (80.1\%) and 78/179 (43.6\%) males and females, respectively. Camel male was almost five times $(\mathrm{OR}=5.22)$ more likely to be infested by ticks than female camel (Table 1). A number of 46/179 (25.7\%) female camels have aborted and all of them $100 \%$ were infested by ticks. However, only 32/133 (24.1\%) of non-aborted camels were infested by ticks (Table 1). Ticks were more prevalent in summer and in camels aged 1-4 years (Table 1). A total number of 298 ticks were collected, including 70 Larvae and 228 adults. Also, 240 and 58 ticks were males and females respectively. The identification of tick species revealed Hyalomma dromedarii Koch, 1844 (90.9\%), Hyalomma impeltatum Schulze and Schlottke, 1930 (5.37\%) and for the first time in Algeria, Amblyomma variegatum Fabricius, $1794(2.35 \%)$ and Rhipicephalus turanicus Pomerantsev, 1936 (1.34\%). Camels were more infested by $H$. dromedarii than other species (Table 2). A number of 46/46 (100\%), $10 / 46(21.7 \%)$ and $3 / 46(6.52 \%)$ of aborted camels were infested by $H$. dromedarii, $H$. impeltatum and $A$. variegatum ticks respectively (Table 2 ). H. dromedarii was isolated throughout the year and H. impeltatum was isolated during the spring season only. A. variegatum and Rh. turanicus were isolated in summer.

Table 1: Relationship between tick's infestation and abortion in camels and other factors

\begin{tabular}{|c|c|c|c|c|c|}
\hline Variable & & $\begin{array}{c}\mathrm{N}^{\circ} \text { of animals } \\
\text { examined }\end{array}$ & $\begin{array}{c}\mathrm{N}^{\circ} \text { of animals infested by } \\
\text { ticks }(\%)\end{array}$ & $\begin{array}{l}\text { Odds ratio (OR) } \\
(\mathrm{CI} ; 95 \%)\end{array}$ & P-value \\
\hline \multirow[t]{2}{*}{ Abortion } & Yes & 46 & $46(100)$ & $145.19(47.77-441.24)$ & 0.000 \\
\hline & No & 133 & $32(24.1)$ & - & \\
\hline \multirow{2}{*}{ Sex } & Male & 171 & $137(80.1)$ & $5.22(3.29-8.28)$ & 0.001 \\
\hline & Female & 179 & $78(43.6)$ & - & \\
\hline \multirow{4}{*}{ Age (year) } & $<1$ & 113 & $33(29.2)$ & $0.12(0.07-0.2)$ & \\
\hline & $1-4$ & 181 & $170(93.9)$ & $42.59(24.11-75.23)$ & 0.001 \\
\hline & $5-8$ & 30 & $7(23.3)$ & $0.16(0.07-0.35)$ & \\
\hline & $>8$ & 26 & $5(19.2)$ & $0.15(0.06-0.36)$ & \\
\hline \multirow[t]{4}{*}{ Season } & Winter & 109 & $32(2.4)$ & $0.13(0.08-0.21)$ & \\
\hline & Spring & 63 & $35(55.6)$ & $0.74(0.42-1.29)$ & \\
\hline & Summer & 98 & $93(94.9)$ & $19.82(9.55-41.12)$ & 0.001 \\
\hline & Autumn & 80 & $55(68.8)$ & $1.51(0.89-2.56)$ & 0.01 \\
\hline
\end{tabular}


Table 2: Proportion of tick species collected from camels in the Oued Souf region

\begin{tabular}{lccc}
\hline Tick species & $\mathrm{N}^{\circ}$ ticks collected & Proportion $(\%)$ & $\mathrm{N}^{\circ}$ infested aborted camels $(\%)$ \\
\hline Hyalomma dromedarii & 271 & $90.9^{*}$ & $46(100)^{*}$ \\
Hyalomma impeltatum & 16 & 5.37 & $10(21.7)$ \\
Amblyomma variegatum & 7 & 2.35 & $3(6.52)$ \\
Rhipicephalus turanicus & 4 & 1.34 & 00 \\
\hline Total & 298 & 100 & \\
\hline
\end{tabular}

* These values are significantly higher than the other values in the same column at $\mathrm{P}<0.05$.

\section{Discussion}

Various bacterial and parasitic diseases have been reported to be the major problems affecting camels (20-22). Ticks are one of the most important parasites affecting the health, productivity and performance of camels by transmitting various pathogens, blood loss and irritation $(19,23)$. In this survey we compared between the abortion rate of female camels and the presence of ticks. Four tick species were identified Hyalomma dromedarii 90.9\%, Hyalomma impeltatum $5.37 \%$ and for the first time in Algeria, Amblyomma variegatum $2.35 \%$ and Rhipicephalus turanicus $1.34 \%$. All aborted camel females have been infested with these ticks except $R h$. turanicus. A total number of 215/350 (61.4\%) camels were found infested by ticks in our study. This prevalence was in agreement with the findings of Moshaverinia and Moghaddas (24) in Iran and Onyiche et al. (25) in Nigeria. On the other hand, our result is lower than that reported by Kiros et al. (26) in Ethiopia and Lawal et al. (27) in Nigeria. Compared to sex type, camel's males were found to be significantly more infested by ticks than females which are in concordance with Kiros et $a l$. (26). Ticks were present on camels throughout the year in our study, which is consistent with the findings of Faye et al. (28) and Qamar et al. (29). On the other hand, ticks were more prevalent in summer in our study, which is in concordance with Moshaverinia and Moghaddas (24), Elias et al. (30), Qamar et al. (31) and Fard et al. (32). This is due to the seasonal activity of ticks which is maximal in summer (19) for the tick species found in our study. H. dromedarii, is the most Hyalomma spp. parasitizing camels (33). In our study, camels were detected more infested by $H$. dromedarii than other species which is in concordance with Al-Deeb et al. (18) in United Arab Emirates, Alanazi et al. (34) in Saudi Arabia, and other parts of the world $(21,23,26,27,35)$. $H$. dromedarii has an important role in the transmission of pathogens as Theileria (36), Rickettsia (19), C. burnetii (14), Anaplasma $(12,13)$ and viruses $(37)$ of which some may be abortive. In our study, H. dromedarii ticks were observed in all abortive camel females which lead us to suspect their potential role in abortions in camel farms.

$H$. dromedarii is the most tick observed on camels which may be related to the adaptation of this type of tick to the hot and dry climate of the Sahara, knowing that it can perform several cycles during the year $(19,38)$. The assembling of camels around the water points of the oases facilitates their infestation, as the oases offer a favorable microclimate for ticks, particularly of the genus Hyalomma (18), which have long legs and actively move in search of the camels (19). $H$. impeltatum shares similar hosts and geographical areas with $H$. dromedarii (19). It has been revealed as a vector for Theileria annulata, an abortive agent in cattle (39). Theileria infection was reported in camels in United Arab Emirates (40) and in Saudi Arabia (34). Theileria infection was reported in camels suffered from symptoms included abortion (34). In our study, all ticks of H. impeltatum were observed on abortive camels which lead us to suspect their potential role in these abortions. The number of $H$. impeltatum ticks collected was 16/298 (5.37\%) which is in concordance with the finding of Elghali and Hassan (35) and higher than the results of Moshaverinia and Moghaddas (24). This difference in the rate of prevalence can be attributed to different climatic conditions, sample size and particularly differences in the sampling periods (24). In our study, A. variegatum was isolated for the first time in Algeria from camels with a percentage of $2.35 \%$ of all collected ticks. This result is consistent with the data provided by Hassan et al. (36), in Egypt, Zeleke and Bekele (41) and Kiros et al. (26), in Ethiopia. A. variegatum ticks are considered one of the most important tick species present in Africa $(19,42)$. It can result in severe economic losses due to milk production reduction and death of livestock (43). It has been implicated as a vector of Ehrlichia ruminantium, heartwater disease (44) and Dermatophilus congolensis, dermatophilosis (45). It also transmits Ehrlichia bovis, causing bovine ehrlichiosis, and the protozoans Theileria mutans and Theileria velifera causing benign bovine theileriosis (19). Rh. turanicus is a typical Rhipicephalus of livestock and Kiros et al. (26). In our study, Rh. turanicus were less prevalent, representing $1.34 \%$ of the ticks found, which is similar to the study described in Saudi Arabia by Alanazi et al. (11) and in Iran by Moshaverinia and Moghaddas (24).

\section{Conclusion}

This preliminary survey provides valuable baseline data on the tick species of one humped camels, their distribution and their potential role in abortion of female camels in Ouargla region, southern Algeria. H. dromedari was the 
most abundant tick and the report of A. variegatum and $R h$. turanicus for the first time in Algeria requires particular attention, especially for public health. In the next step, it is necessary to identify the abortive agents vectorized by these ticks in order to establish an effective control plan.

\section{Acknowledgements}

The authors would like to thank Dr. DHMANI Ali for his precious help in this study as well as the veterinary doctors of Ouargla.

\section{Conflict of interest}

The authors declare that there are no conflicts of interest regarding the publication of this manuscript.

\section{References}

1. Boulanger N, Boyer P, Talagrand-Reboul E, Hansmann Y. Ticks and tick-borne diseases. Med Maladies Infect. 2019;49:87-97. DOI :10.1016/j.medmal.2019.01.007

2. Gubler DJ. Resurgent vector-borne diseases as a global health problem. Emerg Infect Dis. 1998;4(3):442-450. DOI: 10.3201/eid0403.980326

3. Jongejan F, Uilenberg G. The global importance of ticks. Parasitol. 2004;129(1):S3-S14. 10.1017/s0031182004005967

4. Borel N, Thoma R, Spaeni P, Weilenmann R, Teankum K, Brugnera E, Zimmermann DR, Vaughan L, Pospischil A. Chlamydia-related abortions in Cattle from Graubunden, Switzerland. Vet Pathol. 2006;43:702-708. DOI: $10.1354 / v p .43-5-702$

5. Dantas-Torres F, Chomel BB, Otranto D. Ticks and tick-borne diseases:a one health perspective. Trends Parasitol. 2012;28:437-46. DOI: 10.1016/j.pt.2012.07.003

6. Dugat T, Chastagner A, Lagree AC, Petit E, Durand B, Thierry S, Corbiere F, Verheyden H, Chabanne L, Bailly X, Leblond A, Vourc G, Boulouis HJ, Maillard R, Haddad N. A new multiple-locus variablenumber tandem repeat analysis reveals different clusters for Anaplasma phagocytophilum circulating in domestic and wild ruminants. Parasit Vectors. 2014;7:439. DOI: 10.1186/1756-3305-7-439

7. Tibary A, Fite C, Anouassi A, Sghiri A. Infectious causes of reproductive loss in camelids. Theriogenol. 2006;66(3):633-47. DOI: 10.1016/j.theriogenology.2006.04.008

8. Tibary A. Overview of abortion in large animals. New York: CRP press; 2012. 137 p. [available here

9. Afzal M, Sakkir M. Survey of antibodies against various infectious disease agents in racing camels in Abu Dhabi, United Arab Emirates. Rev Sci Tech OIE. 1994;13:787-92. DOI: 10.20506/rst.13.3.794

10. Schelling E, Diguimbaye C, Daoud S, Nicolet J, Boerlin P, Tanner M, Zinsstag J. Brucellosis and Q-fever seroprevalences of nomadic pastoralists and their livestock in Chad. Prev Vet Med. 2003;61:27993. DOI: $10.1016 /$ j.prevetmed.2003.08.004

11. Alanazi AD, Abdullah S, Helps Ch, Wall R, Puschendorf R, Al Harbi SA, Abdel-Shafy S, Shaapan RM. Tick-borne pathogens in ticks and blood samples collected from camels in Riyadh province, Saudi Arabia. Int J Zool Res. 2018;14:30-36. DOI: 10.3923/ijzr.2018.30.36

12. Bastos ADS, Mohammed OB, Bennett NC, Petevinos C, Alagaili AN. Molecular detection of novel Anaplasmataceae closely related to Anaplasma platys and Ehrlichia canis in the dromedary camel (Camelus dromedarius). Vet Microbiol. 2015;179:310-314. DOI: 10.1016/j.vetmic.2015.06.001

13. Belkahia H, Ben Said M, Sayahi L, Alberti A, Messadi L. Detection of novel strains genetically related to Anaplasma platys in Tunisian onehumped camels (Camelus dromedarius). J Infect Dev Contr. 2015;9(10):1117-1125. DOI: $\underline{10.3855 / \text { jidc. } 6950}$
14. Hairgrove T, Schroeder ME, Budkec CM, Rodgers S, Chung C, Ueti MW, Bounpheng MA. Molecular and serological in-herd prevalence of Anaplasma marginale infection in Texas cattle. Prev Vet Med. 2015;119:1-9. DOI: 10.1016/j.prevetmed.2015.02.006

15. Nedjraoui D. Algeria country pasture/forage resource profiles. Rome :FAO;2006. 28 p.

16. Abrhaley A, Leta S. Medicinal value of camel milk and meat. J Appl Anim Res. 2008, 46:1, 552-558. DOI: 10.1080/09712119.2017.1357562

17. Adamou A. L'élevage camelin en Algérie: quel type pour quel avenir? Sécheresse. 2008;19(4):253-60. DOI: 10.1684/sec.2008.0149

18. Al-Deeb MA, Muzaffar SB. Prevalence, distribution on host's body, and chemical control of camel ticks Hyalomma dromedarii in the United Arab Emirates. Vet World. $2020 ; 13(1): 114-120$. DOI: 10.14202/vetworld.2020.114-120

19. Walker AR, Bouattour A, Estrada-Pena A, Horak IG, Latif AA, Pergam RG, Preston PM. Ticks of domestic animal in Africa:a guide to identification of species. UK: Bioscience Reports; 2003. 221 p.

20. Desta AH. Major helminth parasites of Camelus dromedarius in afar pastoral area of Ethiopia. Iraqi J Vet Sci. 2019;33(1):117-122. DOI: 10.33899/ijvs.2019.125524.1046

21. Klaif SF, Saleh ZF, Jawad AA. Molecular characterization of enterohemorrhagic E. coli $\mathrm{O} 157$ and $\mathrm{O} 153$ isolated from tissue camel and human stool samples in Al-Diwaniyah, Iraq. Iraqi $\mathrm{J}$ Vet Sci. 2019;33(1):81-86. DOI: 10.33899/ijvs.2019.125530.1052

22. Mahmood MA, Essa MA. Antimicrobial activity of peptides extracted from camels' blood neutrophils against some pathogenic bacteria. Iraqi J Vet Sci. 2021;35(1):33-37. DOI: 10.33899/ijvs.2020.126239.1270

23. Bekele M. In epidemiological study on major camel diseases in the Borana Lowland, Southern Ethiopia. DCG report No. 58, Drylands coordination group. Oslo; 2010. 68-98 p.

24. Moshaverinia A, Moghaddas E. Prevalence of tick infestation in dromedary camels (Camelus dromedarius) brought for slaughter in Mashhad abattoir, Iran. J Parasit Dis. 2015;39(3):452-455. DOI: 10.1007\%2Fs 12639-013-0367-5

25. Onyiche TE, Răileanu C, Tauchmann O, Fischer S, Vasić A, Schäfer M, Biu AA, Ogo NI, Thekisoe O, Silaghi C. Prevalence and molecular characterization of ticks and tick-borne pathogens of one-humped camels (Camelus dromedarius) in Nigeria. Parasit Vect. 2020;13:428. DOI: 10.1186/s13071-020-04272-2

26. Kiros S, Awol N, Tsegaye Y, Hadush B. Hard ticks of camels in southern zone of Tigray, northern Ethiopia. J Parasit Vector Biol. 2014;6(10):151-155. DOI: 10.5897/JPVB2014.0162

27. Lawal MD, Ameh IG, Ahmed A. Some ectoparasites of Camelus dromedarius in Sokoto, Nigeria. J Entomol. 2007;4:143-148. DOI: 10.3923/je.2007.143.148

28. Faye B, Saint-Martin G, Bonnet P, Bengoumi M, Dia ML. Guide de l'élevage du dromadaire. Sanofi Santé Nutrition Animale: Libourne ; 1997. $126 \mathrm{p}$.

29. Qamar MF, Ayaz MM, Nazir MM. Isolation and identification of ectoparasites in single humped camels (Camelus dromedarius) of Cholistan area, Pakistan. Iraqi J Vet Sci. 2018;32(2):291-297. DOI: 10.33899/ijvs.2019.153866

30. Elias M, Hailu Y, Jilo K. Prevalence, risk factors and species' diversity of ixodid ticks that parasitize dromedary camel in Yabello District of Borana Zone, Southern Ethiopia. 2020;12(2):52-59. DOI: 10.5897/JPVB2019.0377

31. Qamar MF, Ayaz MM, Nazir MM. Isolation and identification of ectoparasites in single humped camels (Camelus dromedarius) of Cholistan area, Pakistan. Iraqi J Vet Sci. 2018;32(2):91-297. DOI: 10.33899/ijvs.2019.153866

32. Fard SR, Fathi S, Asl EN, Nazhad HA, Kazeroni SS. Hard ticks on onehumped camel (Camelus dromedarius) and their seasonal population dynamics in southeast, Iran. Trop Anim Health Prod. 2012;44:197-200. DOI: $10.1007 / \mathrm{s} 11250-011-9909-\mathrm{y}$

33. Alsarraf M, Mierzejewska E.J, Mohallal EME, Behnke JM, Bajer A. Genetic and phylogenetic analysis of the ticks from the Sinai Massif, Egypt, and their possible role in the transmission of Babesia behnkei. Exp Appl Acarol. 2017;72:415-427. DOI: 10.1007/s10493-017-0164-4 
34. Alanazi AD, Nguyen VL, Alyousif MS, Manoj RRS, Alouffi AS, Donato R, Sazmand A, Mendoza-Roldan JA, Dantas-Torres F, Otranto D. Ticks and associated pathogens in camels (Camelus dromedarius) from Riyadh Province, Saudi Arabia. Parasit Vect. 2020;13(1):110. DOI: $10.1186 / \mathrm{s} 13071-020-3973-\mathrm{y}$

35. Elghali A, Hassan SM. Ticks (Acari: Ixodidae) infesting camels (Camelus dromedarius) in Northern Sudan. Onderstepoort Vet Res. 2009;76:177-185. DOI: 10.4102/ojvr.v76i2.43

36. Hassan MI, Gabr HSM, Abdel-Shafy S, Hammad KM, Mokhtar MM. Prevalence of tick-vectors of Theileria annulata infesting the onehumped camels in giza, Egypt. J Egypt Soc Parasitol. 2017;47(2):425432. DOI: $10.12816 /$ jesp. 2017.77797

37. Abdel-Shafy S, Allam NAT. Quantitative real-time RT-PCR detection of flaviviruses associated with camel ticks in Egypt. Glob Vet. 2013;10:394-402. DOI: 10.5829/idosi.gv.2013.10.4.7235

38. Mustafa BH. Detection on ectoparasites on small ruminants and their impact on the tanning industry in Sulaimani province. Iraqi J Vet Sci. 2019;33(2):303-309. DOI: 10.33899/ijvs.2019.162995

39. Gharbi M, Touay A, Khayeche M, Laarif J, Jedidi M, Sassi L, Darghouth MA. Ranking control options for tropical theileriosis in atrisk dairy cattle in Tunisia, using benefit-cost analysis. Rev Scient Tech OIE. 2011;3:763-778. DOI: 10.20506/rst.30.3.2074

40. Al-Deeb MA, Muzaffar SB, Abu-Zeid YA, Enan MR, Karim S. First record of a spotted fever group Rickettsia sp. and Theileria annulata in Hyalomma dromedarii (Acari:Ixodidae) ticks in the United Arab Emirates. Florida Entomol. 2015;98:135-139. DOI: 10.1653/024.098.0123

41. Zeleke M, Bekele M. Species of ticks in camels and their seasonal population dynamics in Eastern Ethiopia. Trop Anim Health Prod. 2004;36:225-231. DOI: 10.1023/B:TROP.0000016830.30194.2a

42. Stachurski F, Lancelot R. Footbath acaricide treatment to control cattle infestation by the tick Amblyomma variegatum. Med Vet Entomol. 2006;20:402-412. DOI: 10.1111/j.1365-2915.2006.00648.x

43. Walker AR. Amblyomma tick feeding in relation to host health. Trop Anim Health Prod. 1996;28:26S-28S. DOI: 10.1007/BF02310695

44. Parola P, Vestris G, Martinez D, Brochier B, Roux V, Raoult D. Tickborne rickettiosis in Guadeloupe, the French West Indies:isolation of Rickettsia africae from Amblyomma variegatum ticks and serosurvery in humans, cattle, and goats. Am J Trop Med Hyg. 1999;60:888-893. DOI: $10.4269 /$ ajtmh. 1999.60.888

45. Allan SA, Barré N, Sonenshine DE, Burridge MJ. Efficacy of tags impregnated with pheromone and acaricide for control of Amblyomma variegatum. Med Vet Entomol. 1998;12:141-150. DOI: 10.1046/j.1365-2915.1998.00080.x

\section{التحقيق في النواقل الرئيسية للأمراض المجهضة في الإبل ذات السنام الواحدة (Camelus dromedarius)}

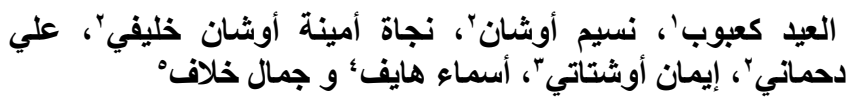

'كلية علوم الطبيعة والحياة بجامعة يحيى فارس المدية، ‘معهد العلوم

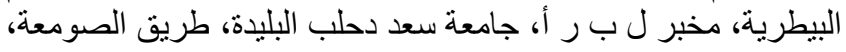

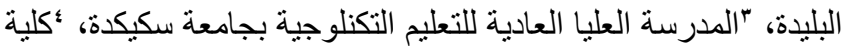

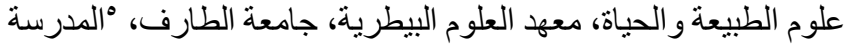
الوطنية العليا للبيطرة، الجز ائر الطعاة

الخلاصة

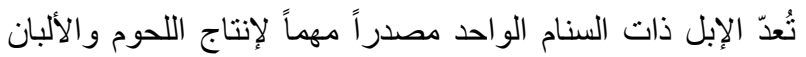
و الجلود للإنسان في جنوب الجزائر دأ تواجه تربية الإبل عقبات عديدة،

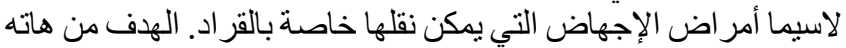

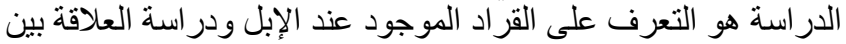

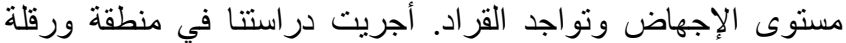

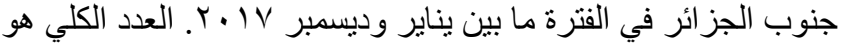

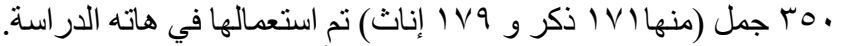
تم تفتيش القراد على كامل جسم الإبل (الر أس و الرقبة و السنام و البطن

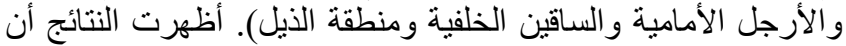

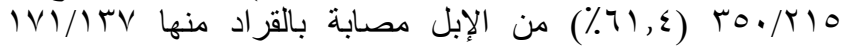

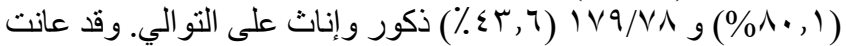

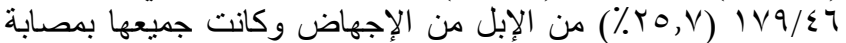

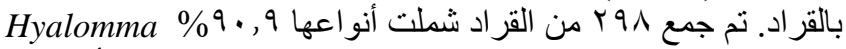
dromedarii الجزائر هب, Amblyomma variegatum \% ـturanicus

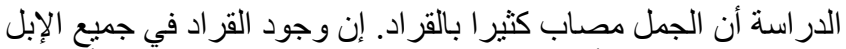

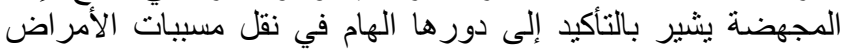

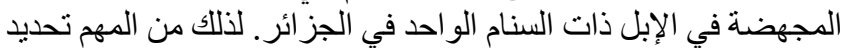

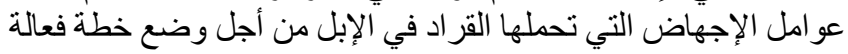

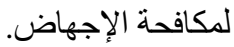

